\title{
狭い空間上で地面効果を受けるホバリングロータの空力性能*1 Aerodynamic Performance of a Rotor Hovering in Close Proximity to Confined Area Ground
}

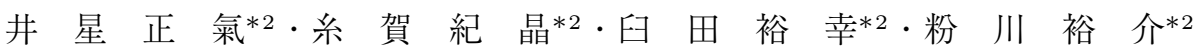 \\ Naohiro IBoshi, Noriaki ItogA, Hiroyuki UsudA and Yuusuke KonAKAWA
}

Key Words : Ground Effect, Aerodynamic Performance, Hovering Rotor, Confined Area

\begin{abstract}
In this study, effects of the confined area geometry on the aerodynamic performance of the hovering rotor are showed from experiments from standpoints of flight safety. The confined area is simulated putting up vertically a single plate or plural plates on the ground effect plate. The aerodynamic performance of the rotor changes because a part of the rotor wake upward along the walls interferes with the flow field around the rotor. It is shown that the behavior of the steady torque coefficients remarkably depends on the combinations among the space between walls, the wall numbers, and the rotor height, and the required torque coefficient increases at all rotor height compared with that above the ground without walls. And also, there is the required torque coefficient in ground effect which can exceed that out-of-ground effect.
\end{abstract}

記 号 の 説 明

$a_{0}:$ コーニング角

$C_{\mathrm{Q}} / \sigma:$ ブレード面積を基準にしたトルク係数

$C_{\mathrm{T}} / \sigma$ : ブレード面積を基準にした推力係数

$h: R$ で無次元化したロー夕高さ

$h_{\mathrm{w}}: R$ で無次元化した壁高さ

$n_{\mathrm{w}}$ : 壁枚数

$R:$ ロ タ半径

$w_{\mathrm{w}}: R$ で無次元化した壁間隔

$w_{\mathrm{wr}}: R$ で無次元化した右壁間隔

$\theta_{0}:$ コレクティブピッチ角

$\sigma:$ ロータソリディティ

$\Omega$ ：ロー夕回転角速度

$$
\text { 1. は じめに }
$$

ヘリコプタは優れたホバリングや低速域における飛行性 能を活用して, 救難救急, 災害派遣, 救急医療等に頻繁に 用いられているが, 今後, このような飛行環境は渓谷やビ ル群のように障害物に囲まれた狭い空間の地面近傍でのホ バリングや, 消音壁のある高速道路上のような左右に壁の ある場所への離着陸も想定される。しかし, 狭い空間上で ホバリングまたはそこに着陸進入する場合には，ボルテッ クスリング状態に陥る可能性が指摘されている11. ヘリコ プタが急降下飛行時にボルテックスリング状態に陥ること

*1 (C) 2010 日本航空宇宙学会

平成 18 年 10 月 18 日, 第 44 回飛行機シンポジウムにおいて一 部発表. 平成 22 年 6 月 23 日原稿受付

*2 防衛大学校システム工学群航空宇宙工学科
は周知の事実であるが，ヘリコプタが急降下飛行をしなく ても狭い空間上の地面近傍でホバリング飛行をする場合に はロータ後流と壁との干渉によるかなりの循環流にもとづ いて操縦が困難になるかもしれない.

国土交通省運輸安全委員会の航空事故インフォメーショ ン2）にもとづいて整理した地域別事故発生状況を第 1 図に 示す. 固定翼航空機の場合は飛行場や場外離着陸場および その周辺における事故が $49 \%$ であるのに対して, ヘリコプ 夕の場合には, 山林・農地や山岳地といった航空輸送手段以 外の任務作業時における事故が $47 \%$ であり, 事故の発生地 域は固定翼航空機と際立った相違を示している。特に，大 規模災害時などでは，操縦者はほとんど初めての飛行環境 での運用を強いられるため, 飛行安全上の観点から, ヘリ コプタロータの空力性能に対する飛行環境の影響を明らか にすることは重要である.

本研究では, ロー夕の空力性能に対する狭い空間の影響 をロータ後流の一部が障害物の壁に沿って上方に向かう流 れとロータおよびロータ後流との間の空力干渉問題と考え て, 模型ロータ, 地面効果板と壁を用いたロータのホバリ ング実験により検討する.

ヘリコプタの飛行安全に関する研究としては, 奥野らが 高層ビル周辺で運用する予定の消火ヘリコプタの安全性を 検証する目的で, ビル周辺での強い乱れを伴う風, いわゆ るビル風の影響を実験的および解析的に検討している ${ }^{3 \sim 5)}$. 一方, 糸賀ら ${ }^{6)}$ と井星ら ${ }^{7)}$ は高層ビル屋上のへリポートや 艦船甲板上への離着陸時に遭遇する Partial Ground Effect を受けるロータの空力性能について, それぞれ数值解析的 および実験的研究を行った。しかし, 狭い空間の影響は壁 の影響を受けたロータ後流とロータとの空力干渉が主要点 

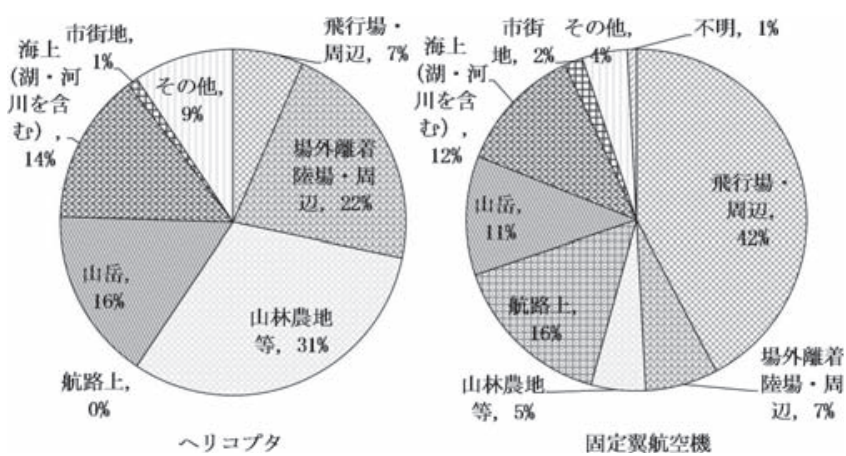

第 1 図 地域別事故発生状況

であり，ボルテックスリング状態に至る因子8,9) を見出す という観点から，ロータの空力性能に対する狭い空間の影 響を論じた研究は筆者らの知る限りではない.

実験では，狭い空間を地面効果板上に垂直に立てた複数 枚の平板により，地面に沿って放射状に広がるロー夕後流 の一部を妨げる壁を設けることによって模擬した，狭い空 間を表すパラメータは壁高さ，壁間隔，壁長さや壁枚数で ある. これらの地面効果パラメー夕を種々に変更して, ロー 夕高さ（ロータ中心から地面効果板までの垂直距離を表す） に対するホバリングロータの推力, トルクやブレードフラッ プ角を測定した，本研究では，狭い空間を規定する地面効 果パラメータのうち, 壁間隔と壁枚数に対するロータ空力 性能の特異な依存性を示す。

\section{2. 実験装置および方法}

実験装置の概要を第 2 図に示す，第 2 図は一対の壁がロー 夕に対して対称に配置された場合を表す。模型ロータは関 節型 2 枚ブレードロータで, 実験室 2 階の床面からトラバー ス装置を介して垂直につり下げることにより，ロータ後流 が模型支持部の影響を受けないようにした。模型ロータの 寸法諸元と実験パラメータを第 1 表に示す.

模型ロータはロー夕推力とトルクを測定するための荷重 検出器を内蔵し，ブレードフラップ角を測定するためのポ テンショメータをフラッピング軸に取付けている。ロータ ブレードの回転方向は上方から見て時計回りである。地面 効果板の中心はロータ中心の真下に位置するように設置し た. 地面効果板は水平で剛な表面をもつ正方形板で, 一辺 の長さは $6.4 R$ である。障害物に囲まれた狭い空間は地面 効果板上に垂直に立てた 1 3 枚の平板で, 地面に沿って ロータ中心から放射状に広がるロータ後流の一部を妨げる 壁を設けることによって模擬した。壁はロータ中心から壁 に下ろした垂線の足が壁の中心となるように配置した，狭 い空間を表すパラメータは壁高さ, 壁間隔, 壁長さ, 壁枚 数である. 壁高さ $h_{\mathrm{w}}$, 壁間隔 $w_{\mathrm{w}}$, 壁長さ $l_{\mathrm{w}}$ とロータ高 さ $h$ はロータ半径 $R$ で割った無次元量で表す.

ロータ高さは模型ロータをトラバース装置で上下方向に 移動することにより約 0.09 ずつ変更した。 トラバース装置 の最大移動距離は $1200 \mathrm{~mm}(2.11 R)$ である.

本実験では，ロー夕高さを変更するごとに推力係数が一

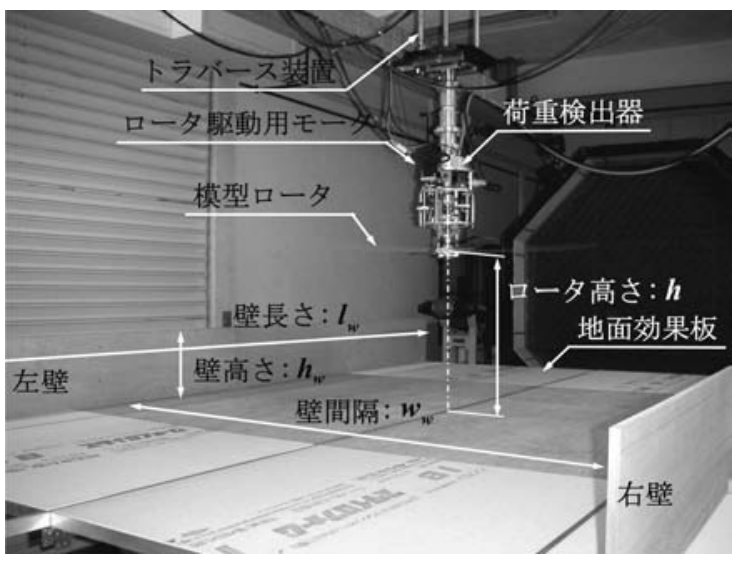

第 2 図 実験装置の概要

第 1 表 模型ロータの寸法諸元と実験パラメータ

\begin{tabular}{ll}
\hline ロータ半径 & $569 \mathrm{~mm}$ \\
ブレード翼弦長 & $60 \mathrm{~mm}$ \\
翼型 & NACA0015 \\
ねじり下げ角 & なし \\
ロータソリディティ & 0.0671 \\
ロータ回転角速度 & $94.2 \mathrm{rad} / \mathrm{s}$ \\
フラッピングヒンジオフセット & 0.03 \\
コレクティブピッチ角 & $4.93 \sim 10.76^{\circ}$ \\
ロータ高さ & $0.43 \sim 2.28$ \\
壁高さ & $0.185,0.25,0.5,0.75,1.0$ \\
壁間隔 & $2.5,3.0,4.0,5.0,6.0$ \\
右壁間隔 & $1.25,1.5,2.0,2.5,3.0$ \\
壁長さ & 6.4 \\
壁枚数 & $0,1,2,3$ \\
推力係数 & $0.0470,0.0740,0.0950$ \\
\hline
\end{tabular}

定になるようにコレクティブピッチ角を変更したが, サイ クリック入力は与えていない. 推力係数の基準值は中型へ リコプタの最大離陸重量と空虚重量のほぼ中間值に相当す る $C_{\mathrm{T}} / \sigma=0.0740$ とした。本実験はホバリング実験であ り, 前進速度や降下速度を与えていないので, ロー夕後流 は地面に向かって垂直に降下するため, 着陸進入時のロー 夕後流の方向とは異なることに注意する必要がある.

\section{3. 結果および考察}

3.1 狭い空間上で地面効果を受けるホバリングロータの 空力性能 ロー夕の左右対称な位置に一対の壁がある地面 近傍でホバリングするロータの空力性能を第 3 図に示す. 壁高さは $h_{\mathrm{w}}=0.75$ で, 壁間隔は $w_{\mathrm{w}}=6.0,5.0,4.0$, $3.0,2.5$ の 5 とおりである. 参照例として, 壁のない場合 を $w_{\mathrm{w}}=\infty$ と表して, 図中に重ね描きした。

第 3 図 (a) はロー夕の推力係数を $C_{\mathrm{T}} / \sigma=0.0740$ (一 定）とするためにロータ高さ $h$ ごとに行ったコレクティブ 入力により決定したコレクティブピッチ角 $\theta_{0}$ を示す. $\theta_{0}$ は本実験範囲のすべての壁間隔とロー夕高さ $h$ に対して壁 のない場合よりも大きくなる。これは壁に沿って上方に向 かうロータ後流の一部がロータと干渉することにより平均 インフローを増大させて, 有効迎え角を小さくするためで 


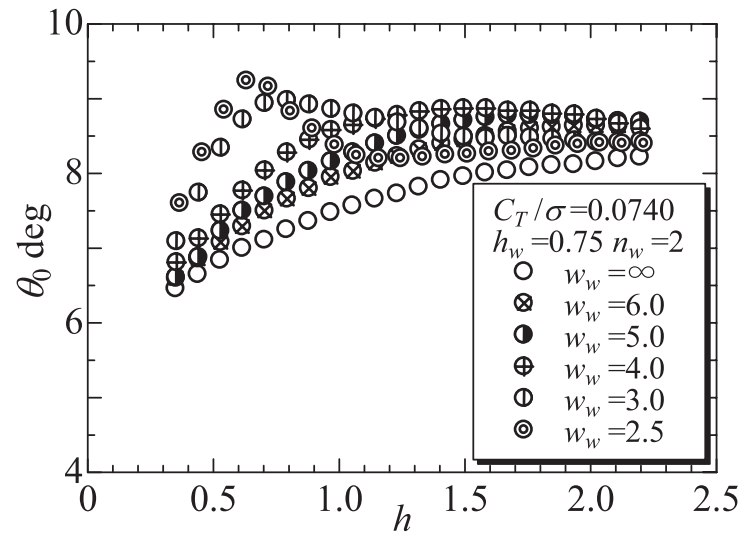

(a) コレクティブピッチ角

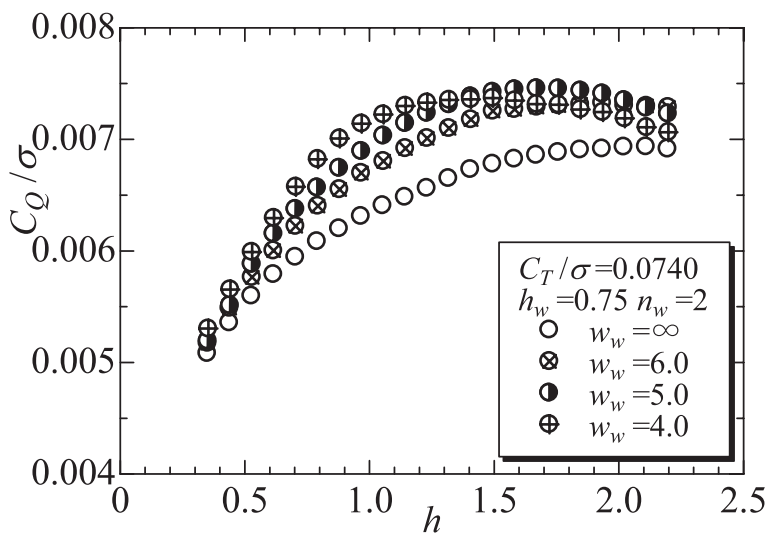

(b) トルク係数 $\left(w_{\mathrm{w}}=6.0 \sim 4.0\right)$

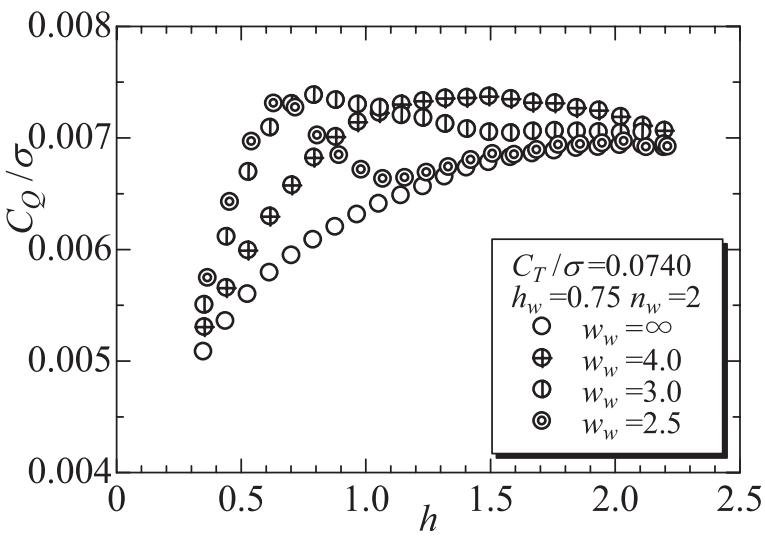

(c) トルク係数 $\left(w_{\mathrm{w}}=4.0 \sim 2.5\right)$

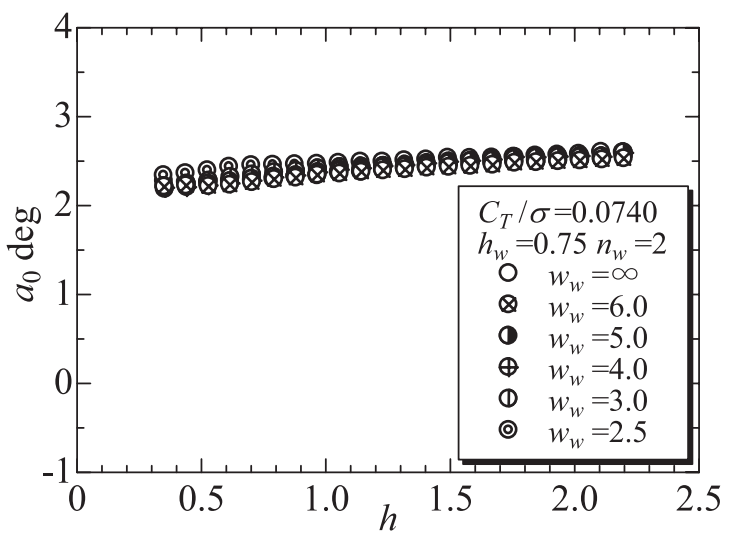

(d) コーニング角

第 3 図 狭い空間上で地面効果を受けるロー夕の空力性能 $\left(n_{\mathrm{w}}=2\right)$

ある。

コレクティブピッチ角に対応した推力係数 $C_{\mathrm{T}} / \sigma$ は適切 なコレクティブ入力により基準值に対して $\pm 0.25 \%$ 以内の 精度で，一定に設定できている.

第 3 図 (b)，(c) は $C_{\mathrm{T}} / \sigma=0.0740$ （一定）としたとき のロータ高さ $h$ に対するトルク係数 $C_{\mathrm{Q}} / \sigma$ を示す. 第 3 図 (b) は壁間隔が $w_{\mathrm{w}}=6.0 \sim 4.0$ の場合, 第 3 図 (c) は壁 間隔が $w_{\mathrm{w}}=4.0 \sim 2.5$ の場合である。第 3 図 (b)では, 一 般に, 地面効果外といわれているロータ高さが 2.0 より大 きな範囲でも， $C_{\mathrm{Q}} / \sigma$ は壁がない場合より大きく，ロータ 高さが小さくなるとともに増大して極大值をとった後, 減 少して壁のない場合に近づく， $C_{\mathrm{Q}} / \sigma$ が極大值をとるロー 夕高さは壁間隔が小さくなるとともに小さくなる。第 3 図 (c) では, $C_{\mathrm{Q}} / \sigma$ は壁がない場合より大きいことと $C_{\mathrm{Q}} / \sigma$ が極大值をとるロー夕高さは壁間隔が小さくなるとともに 小さくなることは第 3 図 (b) と同じであるが, ロー夕高さ に対する挙動が全く異なっている。すなわち、ロー夕高さ が地面効果外に近い比較的大きな範囲では， $C_{\mathrm{Q}} / \sigma$ はロー 夕高さが小さくなると緩やかに増大，または壁がない場合 と同様に減少するが, 壁高さ $h_{\mathrm{w}}$ 近傍のロータ高さで急速 に大きくなって極大值をとり, その後, 壁のない場合に近 づく．壁高さ近傍のロータ高さにおける $C_{\mathrm{Q}} / \sigma$ の急増は壁 に沿って上方に向かう流れによって壁側のロータ面に強い 循環流が存在することを表している。ささらに，ロー夕高さ
が小さくなると，ロータ面に戻る流れの影響よりも地面効 果による誘導速度の低減効果の方が効いて $C_{\mathrm{Q}} / \sigma$ は壁のな い場合に近づくと考えられる。これらの挙動は壁に沿って 上方に向かうロー夕後流の一部とロータとの干渉や壁によ るロータ後流構造の変更にもとづくもので, これらの干渉 効果はロー夕高さや壁間隔の組合せに著しく依存している.

第 3 図 (d) はコーニング角 $a_{0}$ を示す.コーニング角は ロータ高さが小さくなるとともに減少する。この傾向は壁 のない場合と同じで，壁間隔の影響もほとんど見られない. 壁がある場合には, 壁近傍のブレード方位角で壁に沿う上 向き流れの影響を受けるため, インフロー分布はブレード 方位角やロー夕高さとともに複雑に変化するが10), 第 3 図 (d) を見る限り, ロータ半径方向やブレード方位角方向の インフロー分布変更の影響は定常的には小さいといえる.

これらから, 狭い空間上におけるロータの地面効果に対 する注意点は, (1) 壁のない, 水平な地面上と比べて, す ベてのロータ高さでトルク係数が増大する, (2) 地面効果 内にもかかわらず，ロータ高さが小さくなるとともにトル ク係数が増大して極大值をとり, 地面効果外よりも必要卜 ルクが増大するロー夕高さが存在する，ことである。この ような全般的な特徵は地面効果内では性能的に好ましいと いう周知の地面効果とは真逆の現象である。

3.2 トルク係数に対する壁間隔の影響 トルク係数に 対する壁間隔の影響を第 4 図に示す。第 4 図 (a)〜 (e) はそ 


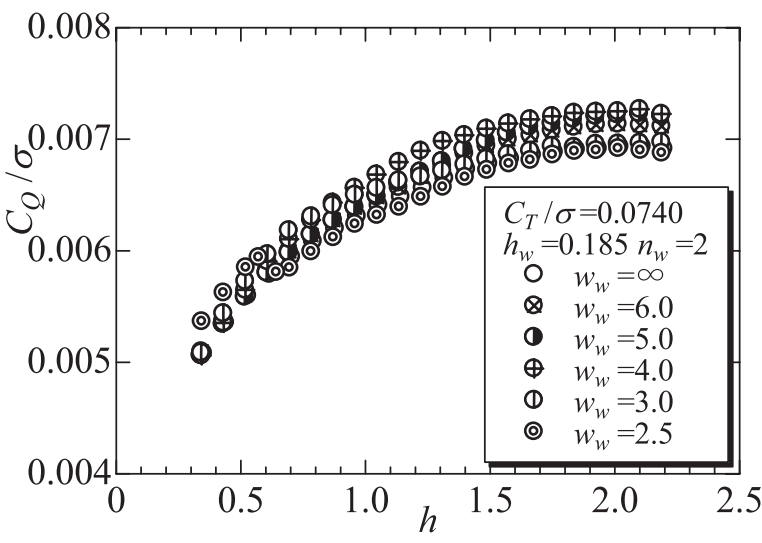

(a) $h_{\mathrm{w}}=0.185$

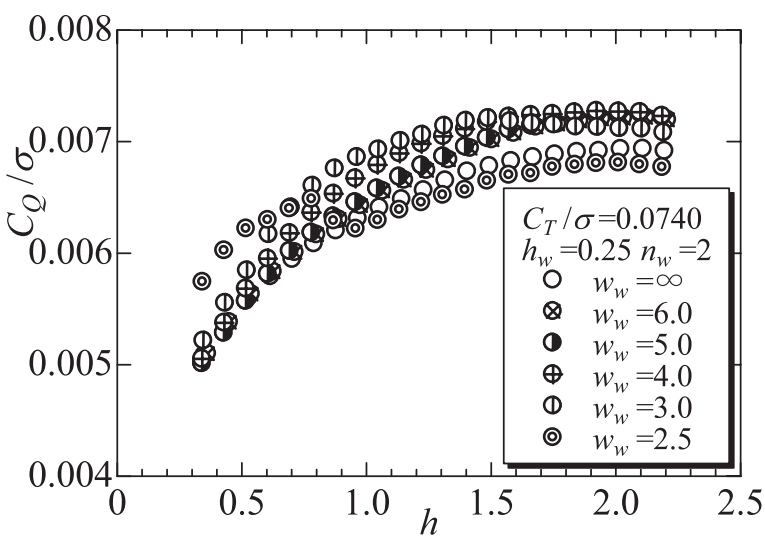

(b) $h_{\mathrm{w}}=0.25$

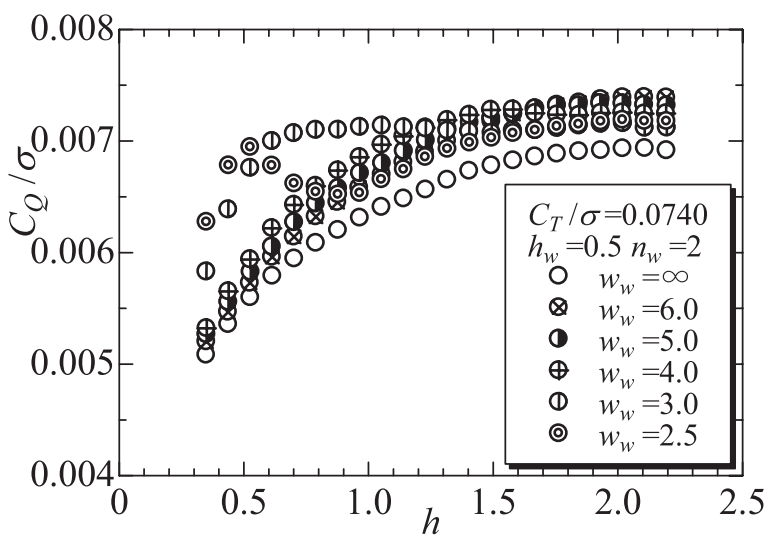

(c) $h_{\mathrm{w}}=0.5$

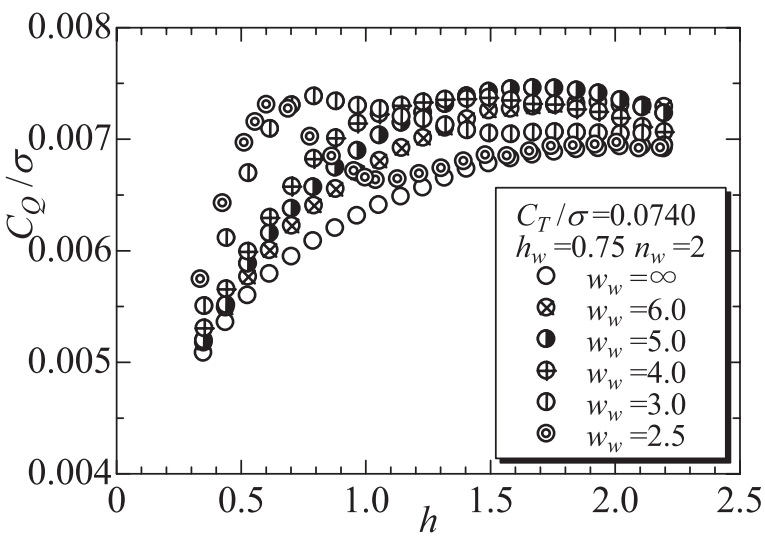

(d) $h_{\mathrm{w}}=0.75$

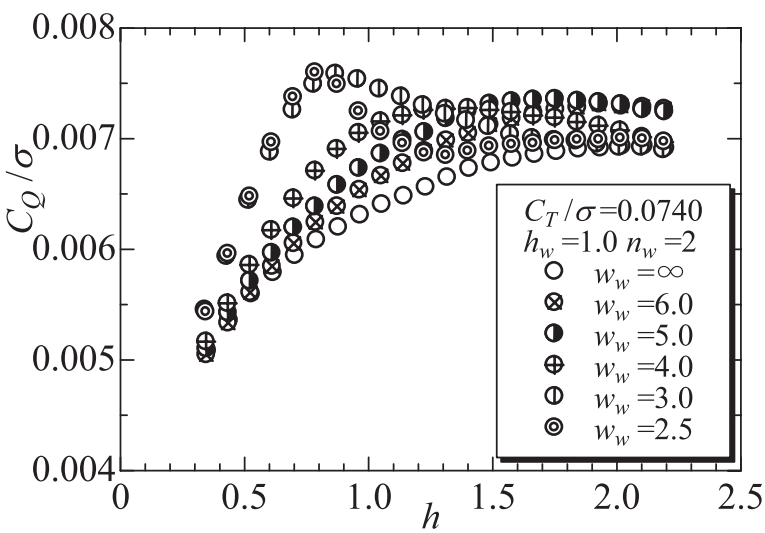

(e) $h_{\mathrm{w}}=1.0$

第4図トルク係数に対する壁間隔の影響（壁高さ一定）

れぞれ壁高さが $h_{\mathrm{w}}=0.185,0.25,0.5,0.75,1.0$ の場合で ある、ただし，第 4 図 (d) は第 3 図 (b) と (c) を再び一つ の図にまとめたものである。第 3 困 (b), (c) で説明した壁 間隔とロータ高さに対するトルク係数の挙動の特徴は第 4 図 (c) と (e) に示すそれぞれの壁高さが $h_{\mathrm{w}}=0.5$ と 1.0 の 場合にも明瞭に現れている。 さらに，壁高さが大きくなる とともに, 壁間隔が $w_{\mathrm{w}} \leq 3.0$ ではトルク係数の極大值と 極大值をとるロー夕高さも大きくなることが分かる.

一方, 壁高さが小さい, $h_{\mathrm{w}}=0.185,0.25$ の場合には, 壁間隔が $w_{\mathrm{w}}=3.0$ のときにも第 4 図 $(\mathrm{c}) \sim(\mathrm{e})$ のように 1.0 より小さいロータ高さでトルク係数が極大值をもつことは
なく, 全般的には第 3 図 (b) のようなロー夕高さに対する挙 動を示す。しかし，これらの壁高さでは壁間隔が $w_{\mathrm{w}}=2.5$ のときに, ロータ高さに対するトルク係数の挙動が急変す る.この場合のトルク係数は, 地面効果外近傍から壁のな い場合より多少小さく, ロー夕高さが小さくなるとともに 壁のない場合と同程度の減少率で減少する。しかし, トル ク係数は, 壁高さが $h_{\mathrm{w}}=0.185$ の場合には, ロータ高 さが $h=0.672 \sim 0.601$ の間で, $h_{\mathrm{w}}=0.25$ の場合には, $h=0.987 \sim 0.810$ の間で突然増大し，その後は再び壁のな い場合と同様の減少率で減少する。トルク係数が急増する このロー夕高さ間では推力係数の変動も大きい.これらの 


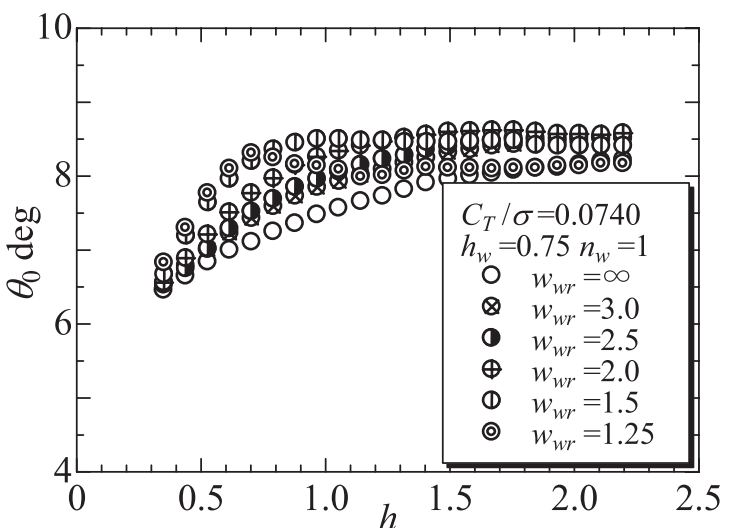

(a) コレクティブピッチ角 $\left(n_{\mathrm{w}}=1\right)$

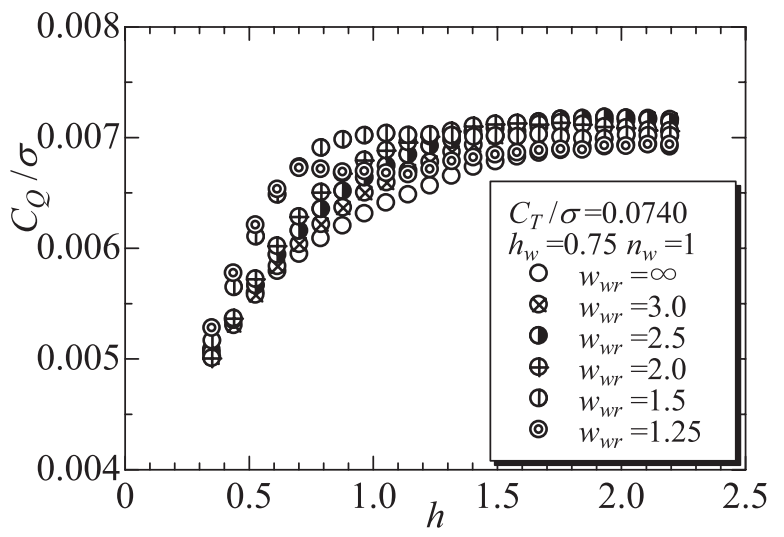

(b) トルク係数 $\left(n_{\mathrm{w}}=1\right)$

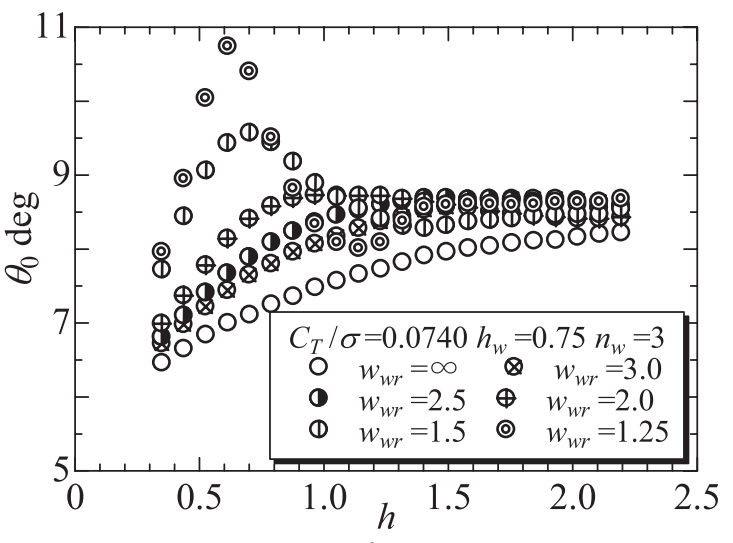

(c) コレクティブピッチ角 $\left(n_{\mathrm{w}}=3\right)$

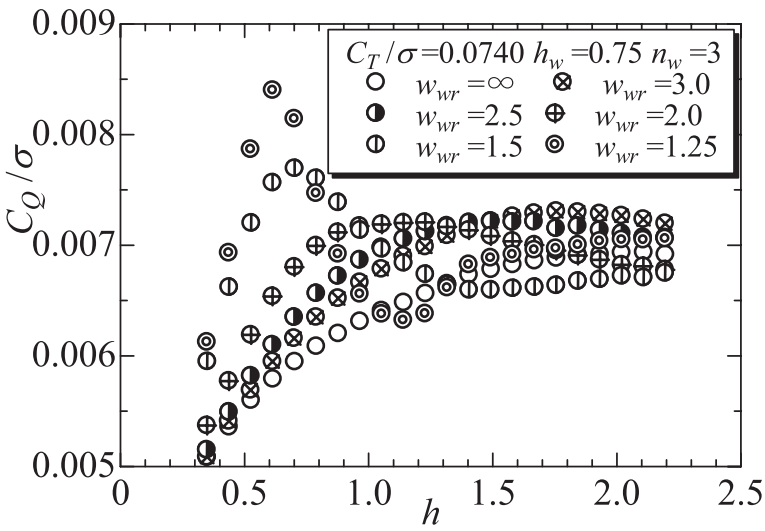

(d) トルク係数 $\left(n_{\mathrm{w}}=3\right)$

第 5 図 トルク係数に対する壁枚数の影響

例では，流れ場が他の条件とは異なっていて，壁の上端か ら多少外向き（ロータと反対向き）の流れとなっていること をタフトにより確認している，壁高さが $h_{\mathrm{w}} \leq 0.25$ で, 壁 間隔が $w_{\mathrm{w}}=2.5$ におけるトルク係数の突然の増大はロー 夕高さの間隔が 0.2 以下のわずかな間で起るため, トルク 係数が小さく, 余剒パワーは十分にあるものの, トルク係 数の増大に対してテールロータ推力を増大させるヨー方向 のつりあいとテールロータ推力の増大に対してロータ面を テールロータ推力と反対方向に傾斜させて横力のつりあい をわずかなロータ高さ間で同時にとる必要と, 推力係数の 変動も加わるために，横のつりあいをとることが難しいと 考えられる。

3.3 壁枚数の影響 第 5 図 (a), (b) はロータの右側だ けに 1 枚の壁がある場合 $\left(n_{\mathrm{w}}=1\right)$ のロータのコレクティブ ピッチ角とトルク係数を, 第 5 図 (c), (d) はロータを中心に して取り囲むように 3 枚の壁がある場合 $\left(n_{\mathrm{w}}=3\right)$ の結果を 示す．壁高さは $h_{\mathrm{w}}=0.75$ である. 壁枚数が $n_{\mathrm{w}}=1,3$ の 場合も推力係数は $C_{\mathrm{T}} / \sigma=0.0740$ (一定) であり, $n_{\mathrm{w}}=2$ の場合と同じ精度で一定に設定できている， $n_{\mathrm{w}}=3$ の場 合の壁配置は $n_{\mathrm{w}}=2$ の場合の平行平板と直交するように さらに 1 枚壁を加えてコの字形とし，ロータ中心から 3 枚 の壁への距離は等しく定めた。そこで，壁間隔は $n_{\mathrm{w}}=1$ の場合と同様に，ロータ中心から右側の壁までの距離を表
す右壁間隔で示した。これに第 3 図 (a) と第 4 図 (d) を含 めて壁枚数の影響を検討する.

第 5 図 (a), (c) から, 壁枚数が $n_{\mathrm{w}}=1,3$ の場合のコレ クティブピッチ角 $\theta_{0}$ は $n_{\mathrm{w}}=2$ の場合と同様に, 壁のな い場合と比べて本実験範囲のロー夕高さ全体にわたって大 きく, 壁に沿うロータ後流とロータとの干渉効果は平均的 には有効迎え角を低減する下向きのインフロー増となって いることが分かる。

第 5 図 (b) から， $n_{\mathrm{w}}=1$ のときのロー夕高さに対するト ルク係数の挙動は $n_{\mathrm{w}}=2$ のときと同様の傾向を示し, す べての右壁間隔に対する $C_{\mathrm{Q}} / \sigma$ は $n_{\mathrm{w}}=2$ の場合の 90〜 $102 \%$ のきさで, 壁が 1 枚だけであるにもかかわらず $n_{\mathrm{w}}=2$ の場合と同様, トルク係数はかなり大きい.

一方, $n_{\mathrm{w}}=3$ の場合には, トルク係数のロー夕高さや 壁間隔に対する全般的な挙動は $n_{\mathrm{w}}=2$ と同じであるが, 右壁間隔が $w_{\mathrm{wr}}=1.25$ と 1.5 のときには, 小さなロータ 高さにおけるトルク係数の増大が極めて大きい. これは循 環流が非常に強くなっているためと考えられる。一方, 右 壁間隔 $w_{\mathrm{wr}}$ が 2.0 より小さくなると, $C_{\mathrm{Q}} / \sigma$ が壁のない場 合よりも小さくなるロータ高さの範囲が存在する。その範 囲は, $w_{\mathrm{wr}}=2.0$ では $1.8<h, w_{\mathrm{wr}}=1.5$ では $1.3<h$, $w_{\mathrm{wr}}=1.25$ では $1.0<h<1.3$ となり, 右壁間隔が小さ くなるとともに小さいロー夕高さに移行している。これは, 


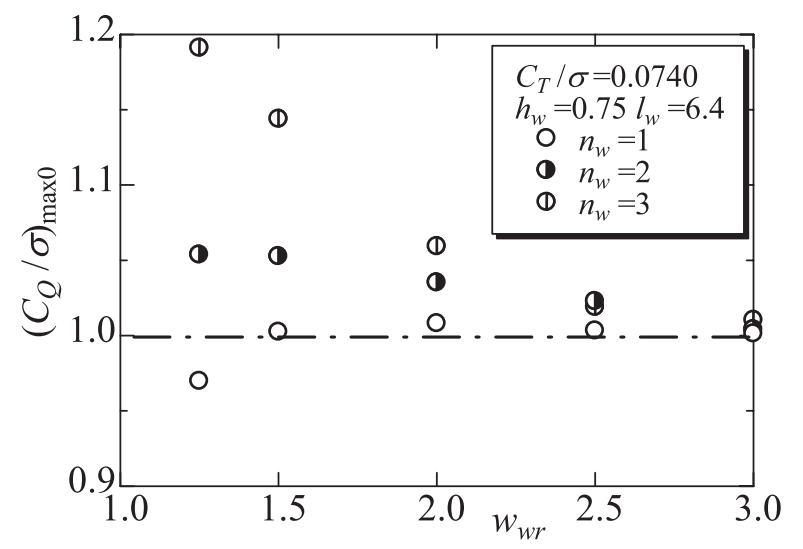

第 6 図 トルク係数の極大值に対する壁枚数と壁間隔の影響

$n_{\mathrm{w}}=3$ の場合には, 壁に沿って上方に向かうロータ後流の 干渉が大きく, 平均的には下向きのインフロー増となって いるが，壁側のロータ面にはアップウォッシュとして作用し ているものと考えられる，そこで， $w_{\mathrm{wr}} \leq 2.0$ での $C_{\mathrm{Q}} / \sigma$ の低減はロータ面のインフロー分布の変更によって空気力 によるブレード回転方向の加速域が翼端側に広がったため と考えられる.

第 6 図にトルク係数の極大值に対する壁間隔と壁枚数 の影響を示す．横軸の壁間隔は壁枚数 $n_{\mathrm{w}}$ の如何にかか わらず右壁間隔 $w_{\mathrm{wr}}$ で表した。 縦軸は地面効果外 $(h>$ 2.0)でのトルク係数の平均值で正規化したトルク係数の 極大值 $\left(C_{\mathrm{Q}} / \sigma\right)_{\max 0}$ を表す. $n_{\mathrm{w}}=2,3$ では, すべての $\left(C_{\mathrm{Q}} / \sigma\right)_{\max 0}$ が 1 より大きく, 地面効果内にもかかわらず, 地面効果外よりも大きなトルク係数を必要とする, すなわ ち地面効果内で必要パワーが増大することを示している. 特 に, $n_{\mathrm{w}}=3$ の場合には, $w_{\mathrm{wr}}=2.0$ で, 地面効果外での必 要卜ルク係数より $6 \%$ 増, $w_{\mathrm{wr}}=1.5$ で $14 \%$ 増, $w_{\mathrm{wr}}=1.25$ では $19 \%$ 増となって, 右壁間隔が小さいと $\left(C_{\mathrm{Q}} / \sigma\right)_{\max 0}$ は 極めて大きくなることが分かる.

3.4 推力係数の影響 第 7 図は一対の壁がある地面上 で地面効果を受けるロータのトルク係数に対する推力係数 $C_{\mathrm{T}} / \sigma$ の影響を示す. 推力係数は $C_{\mathrm{T}} / \sigma=0.0470,0.0950$, 0.0740 とし, それぞれ中型へリコプタの空虚重量, 最大離 陸重量, 両者の中間值に相当する. 壁枚数は $n_{\mathrm{w}}=2$, 壁 高さと壁間隔はそれぞれ, 狭い空間上での地面効果の特徵 を良く表している $h_{\mathrm{w}}=1.0$ と $w_{\mathrm{w}}=4.0$ とした。

第 7 図 (a) は最大離陸重量から空虚重量に相当する推力 係数をとるときのロータ高さに対するトルク係数を示す。困 中には，壁のない場合の実験值も重ね描きした。すべての 推力係数に対して, トルク係数は, すべてのロータ高さで 壁のない場合より大きく，ロー夕高さが地面効果外より小 さくなるとともに増大して極大值をとり, その後, 減少し て壁のない場合の值に近づく.

第 7 図 (b) では, 第 7 図 (a) のトルク係数を地面効果外で のトルク係数の平均值で正規化した $\left(C_{\mathrm{Q}} / \sigma\right)_{0}$ をロータ高 さに対して表した，壁枚数が $n_{\mathrm{w}}=2$, 壁高さが $h_{\mathrm{w}}=1.0$, 壁間隔が $w_{\mathrm{w}}=4.0$ という条件では, トルク係数の極大值

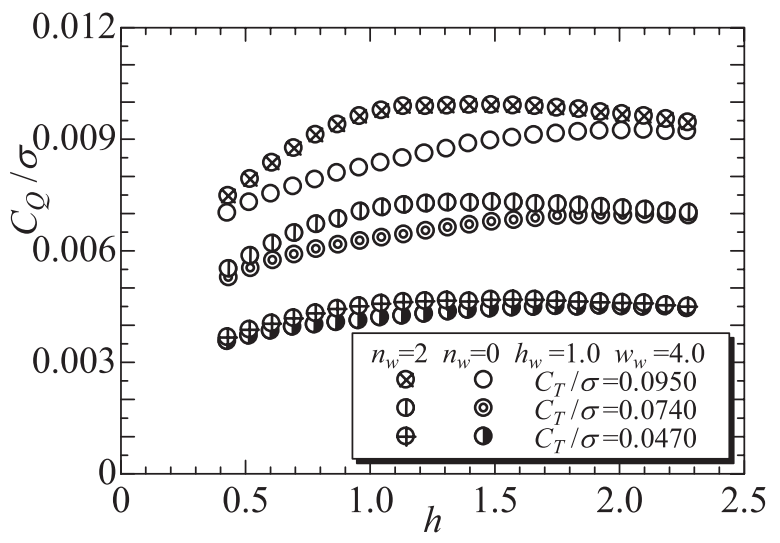

(a) 壁の有無の影響

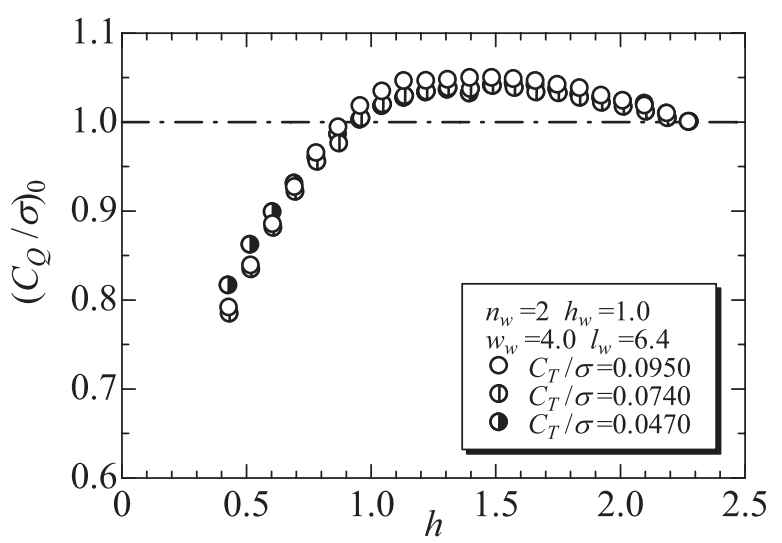

(b) 地面効果外のトルク係数の平均值で正規化したトルク係数

第 7 図 トルク係数に対する推力係数の影響

は地面効果外よりも 4 5\%大きくなった。本条件の範囲で は, すべての推力係数において, ロー夕高さに対するトル ク係数の挙動はほぼ一致しており, 狭い空間上で地面効果 を受けるロータのトルク係数に対する推力係数の影響は小 さいことが確かめられた。

\section{4. おわりに}

狭い空間上で地面効果を受けるホバリングロータの空力 性能を推力係数が一定のもとで実験的に検討し, 壁のある 地面近傍では周知の地面効果とは逆に必要トルク係数が増 大するロー夕高さ, 壁間隔, 壁枚数の組合せが存在するこ とを示した。本研究により得られた知見の詳細はつぎのと おりである。

1）壁のある地面近傍でホバリングするロータは推力係数 が一定のもとでは, 壁間隔, 壁高さ, 壁枚数, ロー夕高さ のほとんどの組合せにおいて，壁のない場合に比べてトル ク係数が増大し, コレクティブピッチ角を増やす必要があ る.コレクティブピッチ角の挙動はロータ面にわたる平均 インフローの増大を示している。

2）地面効果内にもかかわらず，ロータ高さが小さくなる とともにトルク係数が増大して極大值をとり, 地面効果外 よりも必要トルク係数が増大するロー夕高さと壁間隔の組 合せが存在する。

3）本実験範囲では，壁高さが $h_{\mathrm{w}}=0.185,0.25$ で，壁 
間隔が $w_{\mathrm{w}}=2.5$ の場合には, トルク係数が壁のない場合 よりも小さくなる場合がある。しかし，この場合には，1.0 より小さいロー夕高さに打いて，ロー夕高さの間隔が 0.2 以下のわずかな間でトルク倸数が急増し, 推力倸数の変動 増も加わるため, 横のつりあいをとることが困難なロー夕 高さ領域がある。

4）壁高さが $h_{\mathrm{w}}=0.75$ のときには，壁枚数が多くなる と, トルク係数の極大值は大きくなる. たとえば, 壁枚数が $n_{\mathrm{w}}=3$ のときのトルク係数は地面効果外よりも, 右壁間隔 が $w_{\mathrm{wr}}=2.0$ で $6 \%$ 増, $w_{\mathrm{wr}}=1.5$ で $14 \%$ 増, $w_{\mathrm{wr}}=1.25$ では $19 \%$ 増となる。一方，壁のない場合よりもトルク係数 が小さくなるロー夕高さ範囲が存在し，その範囲は右壁間 隔が $w_{\mathrm{wr}} \leq 2.0$ では, 右壁間隔が小さくなるとともに小さ いロータ高さに移行する。このときもコレクティブピッチ 角は壁のない場合よりも大きく, 平均インフローは増大し ているが, 壁に沿って上方に向かうロー夕後流の一部は壁 側のロータ面にアップウォッシュ効果をもたらしていると 考えられる。

5）壁枚数が $n_{\mathrm{w}}=2$, 壁高さが $h_{\mathrm{w}}=1.0$, 壁間隔が $w_{\mathrm{w}}=4.0$ の場合には，推力係数の如何にかかわらず，ロー 夕高さに対するトルク係数の挙動はほぼ一致して㧍り，そ の極大值は地面効果外よりも 4〜 5\%大きい.

\section{参 考 文 献}

1) Taghizad, A., Jimenez, J., Binet, L. and Heuze, D.: Experimental and Theoretical Investigations to Develop a Model of Rotor Aerodynamics Adapted to Steep Descents, Proc. American Helicopter Society 58th Annual Forum, 2002.

2) http://jtsb.mlit.go.jp/jtsb/aircraft/new/air.asp

3) 奥野善則，赤松重樹，齊藤 茂，原田正志：風洞実験による高層 ビル周辺の風の測定一消火ヘリコプタの安全基準に関する基礎実 験一，航空宇宙技術研究所資料，TM-685, 1995, pp. 1-15.

4) 奥野善則, 舩引浩平, 原田正志:ヘリコプタによるビル火災消火 の模擬実験—その 2 消火効率・安全性に及ぼすビル風の影響—, 航空宇宙技術研究所報告, TR-1293, 1996, pp. 1-18.

5）舩引浩平, 奥野善則, 村岡浩治, 若色 薰: ヘリコプタによる火 災消火の模擬実験（その $3 \cdot$ 消火ヘリコプタの運用シミュレーショ ン), 航空宇宙技術研究所報告, TR-1308, 1996, pp. 1-16.

6) 系賀紀晶, 井星正氣：Partial Ground Effect を受けるロー夕 のホバリング性能に対する数值計算, ながれ， 23 (2004), pp. 409-420.

7）井星正氣，糸賀紀晶，早田泰隆，Prasad，J. V. R.：有限な斜面 上でロー夕回転面の一部分が地面効果を受けるロータのホバリン グ性能，日本航空宇宙学会論文集， 51 (2003), pp. 433-440.

8) Basset, P. M., Chen, C., Prasad, J. V. R. and Kolb, S.: Prediction of Vortex Ring State Boundary of a Helicopter in Descending Flight by Simulation, J. Am. Helicopter Soc., 53 (2008), pp. 139-151.

9) Brown, R. E., Leishman, J. G., Newman, S. J. and Perry, F. J.: Blade Twist Effects on Rotor Behavior in the Vortex Ring State, 28th European Rotorcraft Forum Proceedings, Bristol, UK, 2002, pp. 76.1-76.14.

10) 堀元光将: 壁がある地面近傍でホバリングするへリコプタロータ の CFD 解析, 防衛大学校第 47 期理工学研究科修士論文, 2010 . 